\title{
Intellectual Capital and Company Performance: Evidence from European FinTech Companies
}

\author{
Filomena Izzo ${ }^{1}$, Viktoriia Tomnyuk ${ }^{1}$, Giuseppe Varavallo ${ }^{2}$ \\ ${ }^{1}$ Department of Economics, University of Campania “Luigi Vanvitelli”, Capua(CE), Italy \\ ${ }^{2}$ Fondazione LINKS - Leading Innovation \& Knowledge for Society, Torino, Italy \\ Correspondence: Filomena Izzo, University of Campania “Luigi Vanvitelli”, Capua (CE), Italy.
}

\author{
Received: March 25, 2020 \\ Accepted: May 7, 2020 \\ Online Published: May 8, 2020 \\ doi:10.5539/ibr.v13n6p34 \\ URL: https://doi.org/10.5539/ibr.v13n6p34
}

\begin{abstract}
The scope of this study is to examine the impact of Intellectual Capital (IC) on the performance of European FinTech companies. Despite numerous studies conducted to measure the IC, only a few of these explore the impact of IC in dynamic and technological markets. This study intents to contribute to the existing literature by examining a completely new sample of companies that operate in the condition of Industry 4.0. This paper uses data of 12 European Fintech companies from 2016 to 2018, listed in the Dealroom global database. This research employs the Value Added Intellectual Coefficient (VAIC) model proposed by Pulic to measure Intellectual Capital. To obtain accounting information, the authors utilised the Amadeus Bureau van Dijk database.
\end{abstract}

Keywords: FinTech, VAIC model, performance, intellectual capital, Europe

\section{Introduction}

Over the last decennary, a continued advancement founded on new digital technologies has been affecting the entire society by guiding to the diffusion of a digital economy (Gandomi \& Haider, 2015; Raguseo, 2018; Diebold, 2018). We are at the establishment of the fourth industrial revolution, is described by the incorporation of physical activities with new digital ones, from the usage of data in sustain of the industrial activities to the optimization in the implementation of working procedures (Valerdi, 2017; Al-Barznji \& Atanassov, 2017).

In this business condition, knowledge-based competition has grown into the core lead for economic development (Krstic \& Bonic, 2016; Vale et al., 2016; Roos, 2017; Lee \& Wong, 2018). In order to survive over an ever-changing condition, businesses change their strategies from labor-based business to knowledge-based business (Sadalla and Marlina, 2018). As a consequence, IC is a view as the principal sources of a firms competitiveness wealth in this economy era (Petty \& Guthrie, 2000; Petty \& Guthrie, 2000; Marr et al., 2003; Vaz et al., 2015; Roos, 2017; Popkova, 2019). Intellectual Capital includes knowledge, culture, skills, and process strategy that generate value and facilitate the firm to attain its aims (Teece, 2000; Reed et al., 2006; Hsu et al., 2009, Albertini,2016). More studied underline Intellectual Capital as a concealed resource that produces the economic value and influences remarkably the level of competition and success of a business (Ginesti et al., 2018; Marzo \& Scarpino, 2016; Gogan et al., 2016). An enterprise that converts their human, structural and relational capital, which are the components of IC, into information will open its doors to innovations and achieve the ability to act proactively (Fidanbas \& Irban, 2019).

Scholars have investigated the relationships between Intellectual Capital and companies' performance (Meles et al., 2016; Ginesti et al., 2018). Despite numerous studies conducted to measure the IC, just a small number of these study the impact of IC in dynamic and technological markets (Dženopoljac et al.,2016). This study aims to support the existing literature by examining a completely new sample_of companies that operate in the condition of Industry 4.0.: European fintech companies.

Our paper contributes to the literature in that, it offers comprehension of how-to asses Intellectual Capital performance in the European Fintech companies. Furthermore, it recognizes the potential position of Intellectual Capital in fintech company business performance in Europe. This study additionally supports policymakers in attaining their economic stability goal in 4.0 economic Era.

The rest of this paper continues as follows. The ensuing section provides a literature review. Section 3 presents the data, definitions of the variables, and the research methodology. Section 4 offers empirical results of the 
analysis. Section 5 provides discussion, conclusion, and futures research direction.

\section{Literature Review}

The notion of Intellectual Capital is still a topic of current debate for numerous motives. It has no commonly recognized definition, as it is debated in different fields and from diverse viewpoints, comprising economics, strategy, accounting, human resources, marketing, and communication (Lee \& Wong, 2019).

Numerous researches have been conducted to investigate the concept of IC in different industries and countries (Sveiby, 1997; Bontis, 1998; Lev. 2000; Sharabati, 2010; Dženopoljac, 2016).

From the literature, the notion of IC is defined by scholars in numerous ways. Edvinson and Malone (1997) described Intellectual Capital as the ownership of knowledge, skills, customer relationship, strategy, and professional skills that lead added values to the firm. Sullivan (1999) described Intellectual Capital as the knowledge that can be transformed into profit. Herman (2010) defined it as a set of critical skills owned by employees. In numerous cases, Intellectual Capital seems to be vital for the decision making of the firms, and it is the only asset that appreciates over time instead of depreciating (Alhassan and Asare, 2018; D'egidio, 2006).

However, the major scholars agree that IC is composite by three major elements: human capital, structural capital, and relational capital (Subramaniam \& Youndt, 2005; Bjurstrom \& Roberts, 2007).

Human capital refers to people who are part of a firm, especially the knowledge these persons have (White, 2007). Commonly, it refers to the tacit knowledge, such as experience, loyalty, culture, and education that exist in every worker of a firm (McGregor et al., 2004; Tsui et al., 2014). Structural capital is recognized as organizational capital, which includes the organization's procedures, databases, documentation service systems, and other types of codified knowledge (Ting and Lean, 2009; Marzo \& Scarpino, 2016). Relational capital refers to interactions of the company with the external environment; it also comprehends the company's brand, customer loyalty, and corporate reputation (Jayawarna et al., 2014).

IC must be well-comprehended and right managed in companies that it wants to compete effectively in the modern economy. For this reason, to manage the IC well, it is essential to measure and evaluate its performance and improving it regularly. The measurement of Intellectual Capital represents a critical activity for the decision-making process and for the formulation of strategies inside the firms (Roos et al., 2005; Thorleifsdottir and Claessen, 2006). It will, therefore, be even more decisive in the future because of the more competition brought by the development of the fourth industrial revolution.

This study employs the Value Added Intellectual Capital model, which was proposed by Pulic (1998) to measure Intellectual Capital because of its benefits (Iazzolino \& Laise, 2013; Tran \& Vo, 2018). The proposed model is based on the estimate of value added (VA), human capital (HC) structural capital (SC) and capital employed (CE), and has the aim of measuring the capacity of a firm to create value-added thanks to the efficient use of its intellectual capital (Capuano, 2010). The principal advantage of the method is to be founded on public information attainable from the financial statements.

The VAIC model has been extensively tested in various contexts (Ting and Lean, 2009; Celenza et al., 2014) and has been extensively used to measure the relationship between IC and corporate performance of the companies. Joshi et al. (2013) employed the VAIC method to test the effect of Intellectual Capital on financial performance, identifying the Human Capital as the most significant component. Alhassan and Asare (2016) investigate the influence of IC on efficiency in the banking industry in Ghana from 2003 to 2011 using the VAIC model. The author's discovery that VAIC and its elements except for SCE (Structural Capital Efficiency) are positive and significantly linked to variations in productivity. Ginesti et al. (2018) examine the relationship between IC and corporate performance of 452 non-listed Italian companies, proving a positive relationship of VAIC, CEE and SCE with measures of financial performance.

The large body of literature has examined the relationship between IC and the performance of firms operating in traditional sectors, especially in the financial sector. However, only a limited number of these have studied IC in knowledge-intensive industries. Gan and Saleh (2008) examine the relation between Intellectual Capital and financial performance of technological firms in Malaysia, discovering that the firms still depend on CEE (Capital Employed Efficiency). Dženopoljac et al. (2016) study of Serbian ICT firms during 2009-2013, discovered that only Capital Employed Efficiency had a considerable influence on corporate performance. However, no study so far has studied the impact of IC in Fintech companies, most likely because Fintech market is a very recent market. 


\subsection{Research Hypotheses}

Based on these argumentations we propose to test the following two hypotheses:

H1. There is a positive relationship between VAIC and Fintech companies' performance.

H2. There is a positive relationship between VAIC components and Fintech companies' performance.

\section{Method}

\subsection{Overview of the FinTech European Sector}

In the context of the Industry 4.0, new businesses developed. Through the application of enabling technologies such as Blockchain, the Internet of Things, and Artificial Intelligence have entered new players in the financial market, creating a completely new sector, that of Financial Technologies Companies (FinTech).

Fintech is a new financial sector that employs technology to improve financial activities as opposed to traditional financial institutions (Schueffel, 2017). The term "FinTech" is a neologism that derives from the words "financial" and "technology" and generally explains the union of modern Internet technologies, with traditional business activities of the financial services industry (Gomber et al., 2017). Financial technology companies are both startups and established financial institutions, and technology firms attempting to change or improve the use of financial services offered by existing financial institutions. Financial technology has been employed to automate trading, banking services, and risk management (Aldridge \& Krawciw, 2017). Fintech operates in the following area: payment, money management, lending, wealth $\&$ asset management, insurtech, regtech, and tech enabler.

In recent years, the FinTech sector has had a steady development all over the world. Dealroom data report (2019) shows that since 2013 European Fintech companies have created over 2x more value than any tech sector (software, gaming, food, transportation, music, travel, health). In Europe, both realized and current pipeline of private startups (euro $128 \mathrm{~B}$ ).

European fintech investment (\$5.1B) recently surpassed Asia $(\$ 2.2 \mathrm{~B})$ and is not that far from the USA (\$7.5B). However, with the introduction of the European regulation on digital payments (PSD2), European FinTech companies will be able to take advantage of particularly valuable information for free, hitherto held exclusively by banks. Consequently, the European FinTech will be able to accelerate the growth of competition significantly.

The development of the FinTech market is promoted not only by new startups but also by big Internet giants (Google, Apple, Facebook, Amazon), which are gradually expanding its range of activities in the financial sector. Facebook, for example, has recently obtained one e-money (Libra) license in Ireland.

\subsection{Measurement of IC}

Following Pulic (2000), Intellectual Capital value can be determinate through the VAIC method (Value Added Intellectual Coefficient). This method is based on accounting information, which is objective and verifiable. VAIC calculates the efficiency of physical, human, and structural capital. The model is measured as follow:

$$
V A I C=[(V A / H C)+(S C / V A)]+V A / C E
$$

\footnotetext{
$\mathrm{HCE}=\mathrm{VA} / \mathrm{HC} \quad$ where $\mathrm{VA}=$ value added and $\mathrm{HC}=$ total salaries and wages.

$\mathrm{SCE}=\mathrm{SC} / \mathrm{VA} \quad$ where $\mathrm{VA}=$ value added and $\mathrm{SC}=$ structural capital for the company.

$\mathrm{CEE}=\mathrm{VA} / \mathrm{CE} \quad$ where $\mathrm{VA}=$ value added and $\mathrm{CE}=$ book value of the net assets of the firm.
}

The VAIC model was employed in numerous studies (Ting \& Lean, 2009; Celenza et al.,2014). Scholars have investigated, in particular, the relationships between IC and company performance (Meles et al., 2016; Ginesti et al.,2018). Despite numerous studies conducted to measure the IC, just a limited number of these explore the impact of IC in dynamic and technological markets (Dženopoljac et al., 2016).

By analyzing the impact of Intellectual Capital on companies' performance, VAIC and its elements are independent variables. Return on assets (ROA) is used as a performance indicator of companies. 
Table 1. Variables Description

\begin{tabular}{ll}
\hline Variables & Description \\
\hline ROA (return on assets) & Indicator of financial performance \\
VAIC (value added intellectual coefficient) & The sum of HCE, SCE and CEE \\
HCE (human capital efficiency) & Indicator of value-added efficiency of human capital \\
SCE (structural capital efficiency) & Indicator of value-added efficiency of structural capital \\
CEE (capital employed efficiency) & Indicator of value-added efficiency of physical capital \\
\hline
\end{tabular}

\subsection{Regression Models}

This study implements a regression model, testing the relationship between IC and corporate performance. Model (1) analyze the impact of VAIC on companies' corporate performance and model (2) analyze the impact of VAIC components on the company's corporate performance.

$$
\begin{array}{ll}
\text { Model 1: } & R O A=\beta_{0}+\beta_{1} V A I C+\varepsilon \\
\text { Model 2: } & R O A=\beta_{0}+\beta_{1} H C E+\beta_{2} S C E+\beta_{3} C E E+\varepsilon .
\end{array}
$$

\subsection{Data}

This study utilizes data of 12 European financial technology companies from 2016 to 2018, listed in Dealroom global database (providing analytics on startups and venture capital investment). To obtain accounting information, the authors used the Amadeus Bureau van Dijk database. The sample of data was obtained after a selection of only companies with available information for each of the variables listed in Table I. Moreover, the financial technology sector is extremely newly established, and only a few numbers of companies provided data from 2016 to 2018.

\section{Results}

Table 2 shows the mean values of each dependent and independent variables for the year 2016 to 2018 . The first part of Figure 1 shows the composition of VAIC from 12 companies from 2016 to 2018. This first representation is evidence that the component of Human Capital has a higher value for the majority of companies across other components of the VAIC model. The second part of Figure 1 describes VAIC range and how each component of value contributes to forming the final value of VAIC for the 12 FinTech companies.

Table 2. Results from VAIC calculation of 12 European FinTech (2016-2018)

\begin{tabular}{lllll}
\hline HCE & SCE & CEE & VAIC & ROA \\
\hline 2.68 & 0.62 & 0.69 & 3.99 & 26.28 \\
3.62 & 0.72 & 0.38 & 4.72 & 6.41 \\
2.21 & 0.54 & 0.95 & 3.71 & 30.86 \\
3.67 & 0.72 & 0.92 & 5.32 & 18.40 \\
1.77 & 0.43 & 0.82 & 3.02 & -32.92 \\
0.19 & -6.49 & 0.27 & -6.03 & 65.10 \\
6.91 & 0.85 & 2.22 & 9.99 & 8.57 \\
1.60 & 0.37 & 1.33 & 3.30 & -44.37 \\
-0.28 & 1.42 & 0.54 & 1.67 & -11.12 \\
0.32 & 0.65 & 0.23 & 1.20 & -58.29 \\
1.05 & 1.53 & -0.40 & -0.92 & 17.17 \\
\hline
\end{tabular}




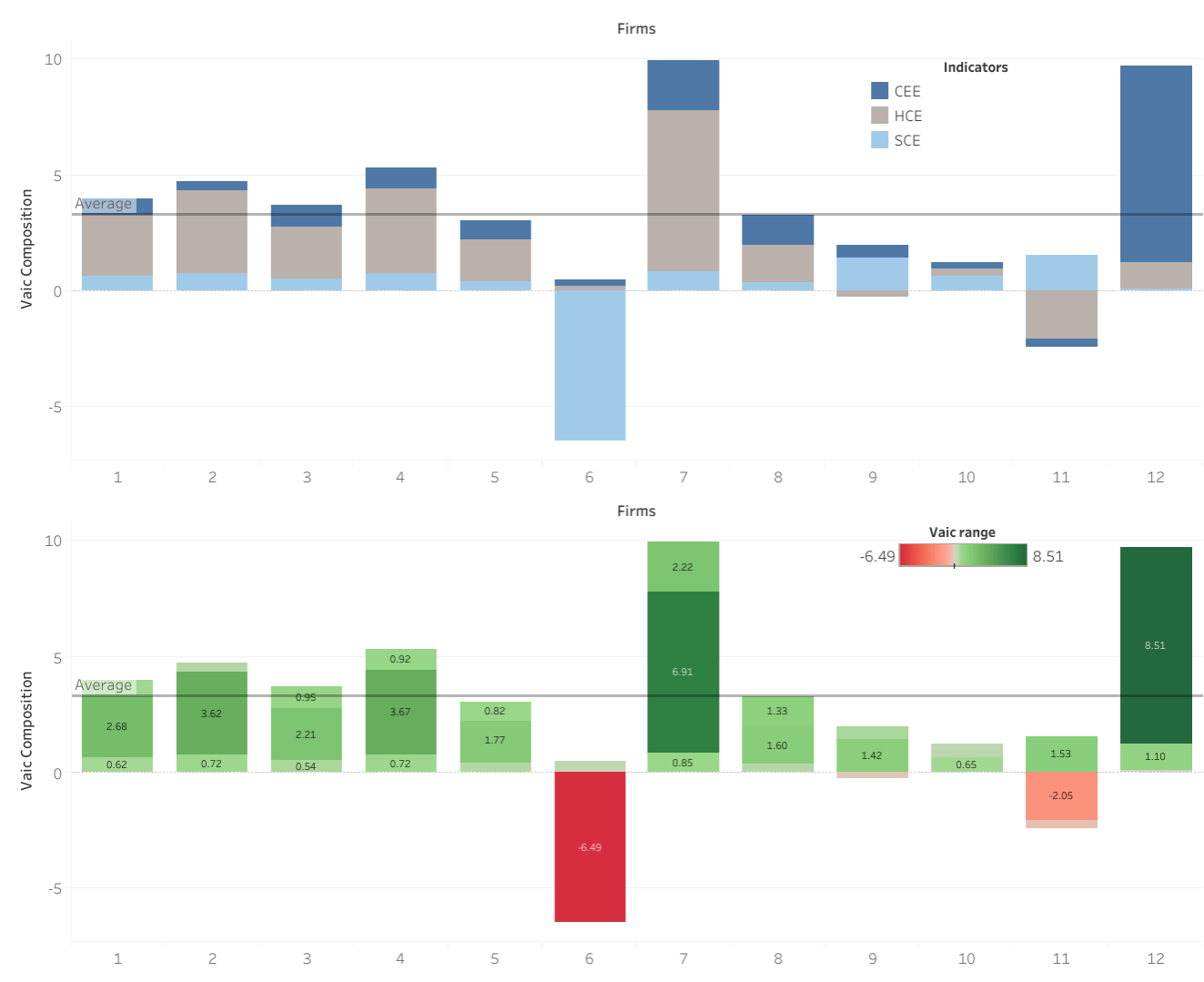

Figure 1. VAIC composition

Before moving on to the regression analysis, it is useful to perform descriptive statistics of the observed variables. In particular, Table 3 shows the minimum, the maximum, the standard deviation, the median, and the average of all the variables taken into consideration for the analysis.

Table 3. Descriptive statistics

\begin{tabular}{lllllll}
\hline Variables & Nr of Firms & Minimum & Maximum & Mean & Median & Std.deviation \\
\hline HCE & 12 & -2.05 & 6.91 & 1.81 & 1.68 & 2.30 \\
SCE & 12 & -6.49 & 1.53 & 0.12 & 0.64 & 2.12 \\
CEE & 12 & -0.40 & 8.51 & 1.37 & 0.75 & 2.34 \\
VAIC & 12 & -6.03 & 9.99 & 3.31 & 3.50 & 4.31 \\
ROA & 12 & -58.29 & 65.10 & 3.16 & 10.21 & 34.67 \\
\hline
\end{tabular}

Table 4 shows the results of the correlation matrix between variables, using Spearman's correlation analysis. Our findings reveal a significantly positive relationship between VAIC and ROA. Also, the outcomes illustrated in Table 4 show that HCE has a high correlation with ROA, and a significative relationship between CEE and ROA, while SCE show a no significative value. This means that investment in Structural Capital in FinTech companies is no impact significantly on their financial performance.

Table 4. Correlation Matrix for HCE, SCE, CEE, VAIC and ROA

\begin{tabular}{llllll}
\hline & HCE & SCE & CEE & VAIC & ROA \\
\hline HCE & & & & & \\
SCE & 0.05 & -0.34 & & & \\
CEE & 0.53 & 0.05 & 0.77 & & \\
VAIC & 0.81 & -0.15 & 0.72 & 0.80 & \\
ROA & 0.86 & & & & \\
\hline
\end{tabular}


The results of regression models are presented in Table 5 and in Figure 2. Model (1) examines the effects of VAIC on ROA. The results reveal a positive relationship between two variables. The estimated coefficient is 6.276 (p-value $=0.002$ ), and the Adjusted R-squared is 0.57, this indicates that the model explains $57 \%$ of the variation in ROA. Therefore, we can confirm the previous hypothesis H1: There is a positive relationship between VAIC and the Fintech company's financial performance. This result confirms the findings of previous studies, for example Ginesti el al. (2018) and Ting \& Hooi (2009).

Model 2 examines the effects of each component of VAIC model on ROA. Table 5 reveals mixed results. Human Capital Efficiency results in a better predictor of company performance with an estimated coefficient of 13.123 and associated p-value $=0.000$. Structural Capital Efficiency with an associated coefficient of 1.570 and p-value $=0.60$, demonstrated a non-significant relationship with ROA indicator. Capital Employed Efficiency with an estimated coefficient of 3.437 and p-value $=0.085$; this means that HCE and CEE are better indicators of company performance. Moreover, the Adjusted R-squared of 0.849 of model 2 suggests that this result is significantly robust.

Table 5. Regression models

\begin{tabular}{lllll}
\hline Variables & & Model 1 & Model 2 \\
& Coefficient & p-value & Coefficient & p-value \\
\hline VAIC & 6.276 & $0.002(* *)$ & & \\
HCE & & & 13.123 & $0.000(* *)$ \\
SCE & & & 1.057 & 0.600 \\
CEE & & & 3.437 & 0.085 \\
$\mathrm{R}^{2}$ Adj & 0.570 & 0.849 & \\
\hline
\end{tabular}

Note. $(* *)$ Significance level p-value $<0.01$.

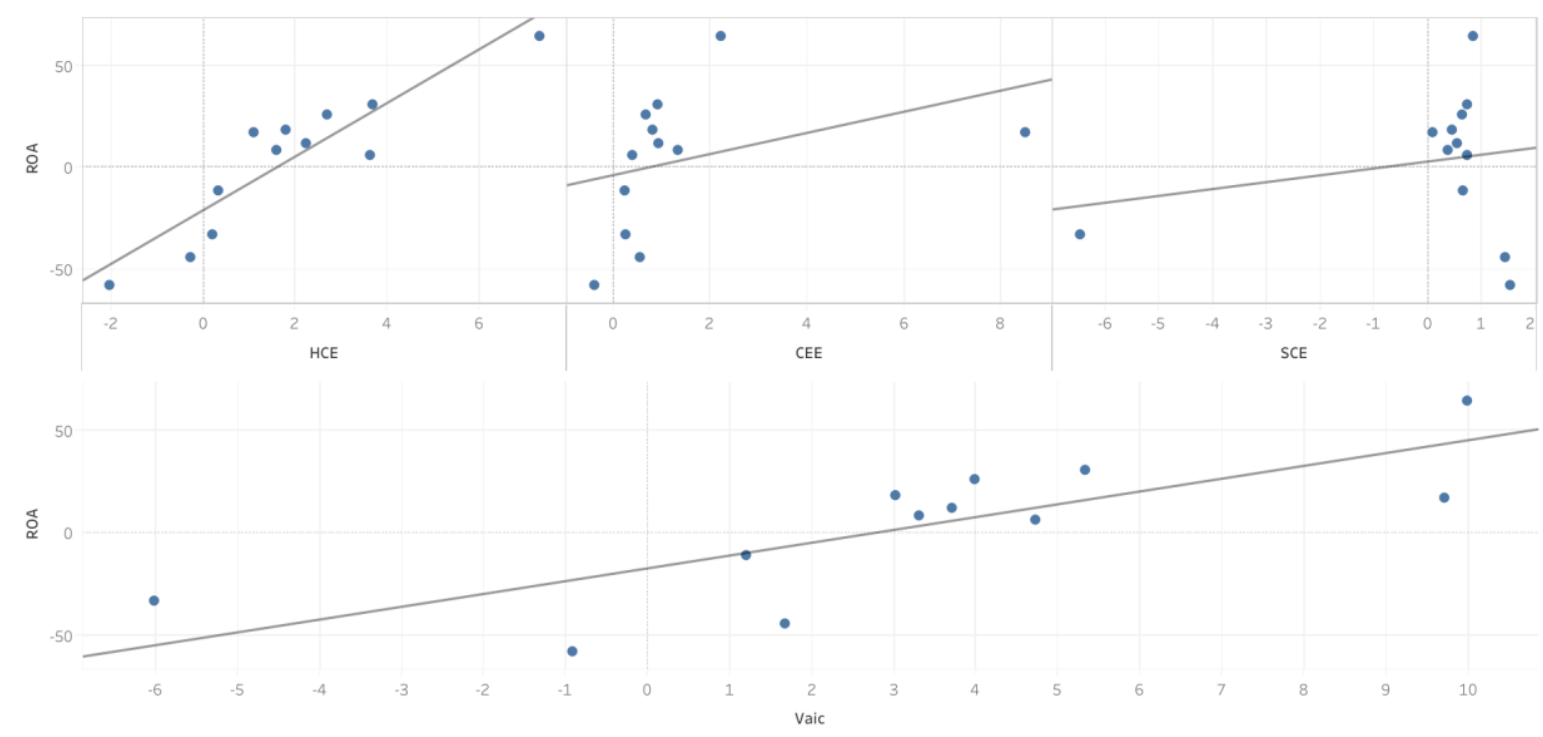

Figure 2. Model 1 and Model 2 regression plots

\section{Discussion and Conclusion}

More studies conducted to measure the IC, just a small number of these investigate the impact of IC in dynamic and technological markets. Our study aims to influence this flow of research by examining a completely new sample of firms that operate in the conditions of Industry 4.0: European fintech companies.

Furthermore, this study provides to comprehending the causal relationship between Intellectual Capital components and the performance of a sample of European Fintech companies, implementing Value Added Intellectual Coefficient (VAIC) model, and evaluating corporate performance.

Results propose that firms concerned in realizing good performance must strengthen their attentiveness to their Human Capital, through a strategy of valuation of employees' abilities, skills, and experience. 
All these outcomes are reliable with the majority of literature that regards the crucial significance of leverage the Intellectual Capital for generating firms' value.

This study might be of awareness to policymakers and shareholders, as it supports to assess how and under what conditions proficient usage of Intellectual Capital components might create value for the competitiveness of firms.

This study, moreover, proposes innovative awareness for managers in order to recognize which aspects are critical for attainment profitability in the 4.0 Technology Era.

Therefore, we suppose that companies with inferior productivity put more and more exertion into obtaining value from the management of the components of Intellectual Capital.

This research has some limits. First, the study focuses on the European level. Future studies could be extended to Asia and the USA market. Second, the outcomes of this research must be taken prudently, pondering the well-known limits that influence the Pulic's method. Third, the study has used only ROA as an indicator of companies' financial performance. More indicators can be involved to analysis the relationship between Intellectual Capital and companies' profitability.

Potential future extension of this research could examine more components of IC, such as Innovation Capital and Relational Capital, these components can capture more information from the external and internal environment. The scholars are invited to test alternative methodological frameworks to calculate IC components and offer a new point of view in this stream of research.

\section{References}

Al-Barznji, K., \& Atanassov, A. (2017). Review of big data and big data mining for adding big value to enterprises. Science, Engineering \& Education, 2(1), 50-57.

Albertini, E. (2016). An inductive typology of the interrelations between different components of intellectual capital. Management Decision. https://doi.org/10.1108/MD-09-2015-0425

Aldridge, I., \& Krawcinw, S. (2017). Real-time risck: what investors should know about fintech, high-frequency trading and flash crashes. Hoboken: Wiley. https://doi.org/10.1002/9781119319030

Alhassan, A. L., \& Asare, N. (2016). Intellectual capital and bank productivity in emerging markets: evidence from Ghana. Management Decision, 54(3), 589-609. https://doi.org/10.1108/MD-01-2015-0025

Bjurström, E., \& Roberts, H. (2007). The principle of connectivity: networked assets, strategic capabilities and bundled outcomes. Intellectual Capital Revisited: Paradoxes in the Knowledge Intensive Organization, Edward Elgar, Cheltenham, 45-60.

Bontis, N. (1998). Intellectual capital: an exploratory study that develops measures and models. Management decision. https://doi.org/10.1108/00251749810204142

Capuano, P. (2010). La valutazione del capitale intellettuale in banca: un'analisi empirica sulle banche italiane quotate. Impresa Progetto-Electronic Journal of Management, 1.

Celenza, D., \& Rossi, F. (2014). Intellectual capital and performance of listed companies: empirical evidence from Italy. Measuring Business Excellence, 18(1), 22-35. https://doi.org/10.1108/MBE-10-2013-0054

D'Egidio, F. (2006). Quando cambiare. Come assicurarsi profitti nel tempo misurando la vitalità d'impresa e gli «intangibili» che contano per vincere (Vol. 326). FrancoAngeli.

Diebold, F. X. (2012, 2018). The Origin(s) and Development of "Big Data": The Phenomenon, the Term, and the Discipline. Manuscript, Department of Economics, University of Pennsylvania. 2012, revised 2018. https://doi.org/10.2139/ssrn.2202843

Dženopoljac, V., Janoševic, S., \& Bontis, N. (2016), Intellectual capital and financial performance in the Serbian ICT industry. Journal of Intellectual Capital, 17(2), 373-396. https://doi.org/10.1108/JIC-07-2015-0068

Edvinsson, L. (1997). Developing intellectual capital at Skandia. Long range planning, 30(3), 366-373. https://doi.org/10.1016/S0024-6301(97)90248-X

Edvinsson, L., \& Malone, M. S. (1997). Intellectual capital: The proven way to establish your company's real value by finding its hidden brainpower. Piatkus.

Fidanbas, O., \& Irdan, G. (2019). The Impact of Intellectual Capital on Innovation: A Literature Study. Business Management Dynamics, 8(12), 1. 
Gan, K., \& Saleh, Z. (2008). Intellectual capital and corporate performance of technology-intensive companies: Malaysia evidence. AJBA, l(1), 113-130.

Gandomi, A., \& Haider M. (2015). Beyond the hype: Big data concepts, methods, and analytics. International Journal of Information Management, 35(2), 137-144. https://doi.org/10.1016/j.ijinfomgt.2014.10.007

Ginesti G., Caldarelli A., \& Zampella, A. (2018). Exploring the impact of intellectual capital on company reputation and performance. Journal of Intellectual Capital, 19(5), 915-934. https://doi.org/10.1108/JIC-01-2018-0012

Gogan, L. M., Artene, A., Sarca, I., \& Draghici, A. (2016). The impact of intellectual capital on organizational performance. Procedia-social and behavioral sciences, 221, 194-202. https://doi.org/10.1016/j.sbspro.2016.05.106

Gomber, P., Koch, J. A., \& Siering, M. (2017). Digital Finance and FinTech: current research and future research directions. Journal of Business Economics, 87(5), 537-580. https://doi.org/10.1007/s11573-017-0852-x

Herman, A. (2010). Intellectual capital and its measurements. Economics \& Business Administration Journal, 2 , $7-16$.

Hsu, Y. H., \& Fang, W. (2009). Intellectual capital and new product development performance: The mediating role of organizational learning capability. Technological Forecasting and Social Change, 76(5), 664-677. https://doi.org/10.1016/j.techfore.2008.03.012

Iazzolino, G., \& Laise, D. (2013). Value added intellectual coefficient (VAIC) A methodological and critical review. Journal of Intellectual Capital, 14(4), 547-563. https://doi.org/10.1108/JIC-12-2012-0107

Jayawarna, D., Jones, O., \& Macpherson, A. (2014). Entrepreneurial potential: The role of human and cultural capitals. International Small Business Journal, 32(8), 918-943. https://doi.org/10.1177/0266242614525795

Joshi, M., Cahill, D., Sidhu, J., \& Kansal, M. (2013). Intellectual capital and financial performance: an evaluation of the Australian financial sector. Journal of intellectual capital, 14(2), 264-285. https://doi.org/10.1108/14691931311323887

Krstić, B., \& Bonić, L. (2016). EIC: a new tool for intellectual capital performance measurement. Prague economic papers, 2016(6), 723-741. https://doi.org/10.18267/j.pep.586

Lee, C. S., \& Wong, K. Y. (2019). Advances in intellectual capital performance measurement: a state-of-the-art review. The Bottom Line. https://doi.org/10.1108/BL-12-2018-0051

Lev, B. (2000). Intangibles: Management, measurement, and reporting. Brookings institution press.

Marr, B., Gupta, O., Pike, S., \& Roos, G. (2003). Intellectual capital and knowledge management effectiveness. Management decision. https://doi.org/10.1108/00251740310496288

McGregor, J., Tweed, D., \& Pech, R. (2004). Human capital in the new economy: devil's bargain? Journal of Intellectual Capital. https://doi.org/10.1108/14691930410512978

Meles, A., Porzio, C., Sampagnaro, G., \& Verdoliva, V. (2016). The impact of the intellectual capital efficiency on commercial banks performance: Evidence from the US. Journal of Multinational Financial Management, 36, 64-74. https://doi.org/10.1016/j.mulfin.2016.04.003

Petty, R., \& Guthrie, J. (2000). Intellectual capital literature review: measurement, reporting and management. Journal of intellectual capital, 1(2), 155-176. https://doi.org/10.1108/14691930010348731

Popkova, E. G. (2019). Preconditions of formation and development of industry 4.0 in the conditions of knowledge economy. In Industry 4.0: Industrial Revolution of the 21 st Century (pp. 65-72). Springer, Cham. https://doi.org/10.1007/978-3-319-94310-7_6

Popkova, E. G., Ragulina, Y. V., \& Bogoviz, A. V. (2019). Fundamental differences of transition to industry 4.0 from previous industrial revolutions. In Industry 4.0: Industrial Revolution of the 21 st Century (pp. 21-29). Springer, Cham. https://doi.org/10.1007/978-3-319-94310-7_3

Pulic, A. (1998). Measuring the performance of intellectual potential in knowledge economy. Paper presented at the second McMaster World Congress on Measuring and Managing Intellectual Capital by the Austrian Team for Intellectual Potential, Hamilton, February.

Pulic, A. (2000). VAIC ${ }^{\text {TM}}{ }_{-a n}$ accounting tool for IC management. International journal of technology management, 20(5-8), 702-714. https://doi.org/10.1504/IJTM.2000.002891 
Raguseo, E. (2018). Big data technologies: An empirical investigation on their adoption, benefits and risks for companies. International Journal of Information Management, 38(1), 187-195. https://doi.org/10.1016/j.ijinfomgt.2017.07.008

Reed, K. K., Lubatkin, M., \& Srinivasan, N. (2006). Proposing and testing an intellectual capital-based view of the firm. Journal of management studies, 43(4), 867-893. https://doi.org/10.1111/j.1467-6486.2006.00614.x

Roos, G. (2005). Intellectual capital and strategy: a primer for today's manager. Handbook of business strategy. https://doi.org/10.1108/08944310510557134

Roos, G. (2017). Knowledge management, intellectual capital, structural holes, economic complexity and national prosperity. Journal of Intellectual Capital. https://doi.org/10.1108/JIC-07-2016-0072

Sadalia, I., \& Marlina, L. (2018). Brand Value, Intellectual, and Financial Performance in Indonesia Stock Exchange. KnE Social Sciences. https://doi.org/10.18502/kss.v3i10.3428

Schueffel, P. (2017). Taming the Beast: A Scientific Definition of Fintech. Journal of Innovation Management, 4(4), 32-54. https://doi.org/10.24840/2183-0606_004.004_0004

Sharabati, A. A. A., Jawad, S. N., \& Bontis, N. (2010). Intellectual capital and business performance in the pharmaceutical sector of Jordan. Management decision. https://doi.org/10.1108/00251741011014481

Subramaniam, M., \& Youndt, M. A. (2005). The influence of intellectual capital on the types of innovative capabilities. Academy of Management journal, 48(3), 450-463. https://doi.org/10.5465/amj.2005.17407911

Sullivan, P. H. (1999). Profiting from intellectual capital. Journal of Knowledge Management. https://doi.org/10.1108/13673279910275585

Sveiby, K. E. (1997). The intangible assets monitor. Journal of Human Resource Costing \& Accounting. https://doi.org/10.1108/eb029036

Teece, D. J. (2000). Managing intellectual capital: Organizational, strategic, and policy dimensions. OUP Oxford.

Thorleifsdottir, A., \& Claessen, E. (2006). Nordic Harmonized Knowledge Indicators: Putting IC into Practice. Nordic Innovation Centre, Reykjavik.

Ting, I. W. K., \& Lean, H. H. (2009). Intellectual capital performance of financial institutions in Malaysia. Journal of Intellectual capital. https://doi.org/10.1108/14691930910996661

Tran, D. B., \& Vo, D. H. (2018). Should bankers be concerned with Intellectual capital? A study of the Thai banking sector. Journal of Intellectual Capital, 19(5), 897-914. https://doi.org/10.1108/JIC-12-2017-0185

Tsui, E., Wang, W. M., Cai, L., Cheung, C. F., \& Lee, W. B. (2014). Knowledge-based extraction of intellectual capital-related information from unstructured data. Expert systems with Applications, 41(4), 1315-1325. https://doi.org/10.1016/j.eswa.2013.08.029

Vale, J., Branco, M. C., \& Ribeiro, J. (2016). Individual intellectual capital versus collective intellectual capital in a meta-organization. Journal of Intellectual Capital. https://doi.org/10.1108/JIC-05-2015-0044

Valerdi, R. (2017). When it's big data and when it's not. ISE Magazine, 49(2), 26.

Vaz, C. R., \& Zarelli, P. R. (2015). Measurement Models of Intellectal Capital for the Decision Making and Performance Variables. Global Journal of Management and Business Research.

White, G., Lee, A., \& Tower, G. (2007). Drivers of voluntary intellectual capital disclosure in listed biotechnology companies. Journal of intellectual capital. https://doi.org/10.1108/14691930710774894

Zambon, S., Marzo, G., \& Scarpino, E. (2016). Exploring intellectual capital management in SMEs: an in-depth Italian case study. Journal of Intellectual Capital. https://doi.org/10.1108/JIC-09-2015-0075

\section{Copyrights}

Copyright for this article is retained by the author(s), with first publication rights granted to the journal.

This is an open-access article distributed under the terms and conditions of the Creative Commons Attribution license (http://creativecommons.org/licenses/by/4.0/). 